\title{
Synthesis of Iron Oxide Nanoparticles Using Isobutanol
}

\author{
Diana Kostyukova and Yong Hee Chung \\ Department of Chemistry, Hallym University, 1 Hallymdaehak-gil, 24252 Chuncheon, Republic of Korea \\ Correspondence should be addressed to Yong Hee Chung; yhchung@hallym.ac.kr
}

Received 22 July 2016; Accepted 14 August 2016

Academic Editor: Bohayra Mortazavi

Copyright (C) 2016 D. Kostyukova and Y. H. Chung. This is an open access article distributed under the Creative Commons Attribution License, which permits unrestricted use, distribution, and reproduction in any medium, provided the original work is properly cited.

\begin{abstract}
Iron oxide nanoparticles were synthesized by precipitation in isobutanol with sodium hydroxide and ammonium hydroxide. The isobutanol played a role of a surfactant in the synthesis. The nanoparticles were calcined for 100 min to 5 hours in the range of 300 to $600^{\circ} \mathrm{C}$. The characterization of the samples by FTIR (Fourier-transform infrared) and XRD (X-ray diffraction) confirmed the formation of $\gamma-\mathrm{Fe}_{2} \mathrm{O}_{3}$ (maghemite) from $\mathrm{Fe}_{3} \mathrm{O}_{4}$ (magnetite) at calcination at $300^{\circ} \mathrm{C}$. The morphology and particle size were studied by SEM (scanning electron microscope). Nanoparticles in the range of $11-22 \mathrm{~nm}$ prepared at $0.09 \mathrm{M}$ of ferrous chloride exhibited superparamagnetic properties. Nanoparticles synthesized with ferrous chloride and ammonium hydroxide at $75^{\circ} \mathrm{C}$ and calcined at $530^{\circ} \mathrm{C}$ for $2 \mathrm{~h}$ were $\alpha-\mathrm{Fe}_{2} \mathrm{O}_{3}$ (hematite).
\end{abstract}

\section{Introduction}

The synthesis of magnetic iron oxide nanoparticles has drawn much interest due to the fact that the characteristics of nanoparticles vary significantly with its procedure. The two major chemical formulas of iron oxide nanoparticles are $\mathrm{Fe}_{3} \mathrm{O}_{4}$ as magnetite and $\mathrm{Fe}_{2} \mathrm{O}_{3}$ as $\gamma-\mathrm{Fe}_{2} \mathrm{O}_{3}$ (maghemite) and $\alpha-\mathrm{Fe}_{2} \mathrm{O}_{3}$ (hematite). Magnetite and maghemite exhibit superparamagnetic properties and high saturation magnetization, leading to their biomedical applications [1-4] such as tumor targeting [5-12] and magnetic resonance imaging [13, 14].

Magnetite and maghemite have been synthesized by coprecipitation of ferrous/ferric salts [15-17], thermal decomposition of hydrazinated iron(II) oxalate [18], microemulsion [19], and sol-gel syntheses [20], hydrolysis, and pyrosol [21]. In the coprecipitation, the size and morphology of nanoparticles vary with synthesis conditions such as iron salts and their concentration, surfactants, $\mathrm{pH}$, and temperature $[1,3,17,22]$. Magnetite is transformed to maghemite by calcination in air as $4 \mathrm{Fe}_{3} \mathrm{O}_{4}+\mathrm{O}_{2} \rightarrow 6 \gamma-\mathrm{Fe}_{2} \mathrm{O}_{3}$. Magnetite has a spinel structure with $\mathrm{Fe}^{3+}$ in all tetrahedral and $\mathrm{Fe}^{3+}$ and $\mathrm{Fe}^{2+}$ in octahedral sites, while maghemite has the same structure with cationic vacancies in one-third of octahedral sites [3]. The cationic vacancies of the transformed maghemite are affected by its preparation and consequently its magnetic properties such as saturation magnetization, remanent magnetization, and coercivity can be varied [16, 17, 21, 23]. Superparamagnetic properties have been shown in magnetite, maghemite, and hematite [24], where well-defined hematite nanoparticles of $41 \mathrm{~nm}$ showed superparamagnetic properties. Superparamagnetic nanoparticles with high saturation magnetization can be synthesized in air $[25,26]$.

In the present work magnetic iron nanoparticles were prepared by precipitation using one iron salt and isobutanol, which was expected to play a role of a surfactant. Ferrous chloride and ferric nitrate were individually used in the synthesis process where $\mathrm{NaOH}$ and $\mathrm{NH}_{4} \mathrm{OH}$ were used as a base. The resulting nanoparticles were calcined for $100 \mathrm{~min}$ to $5 \mathrm{~h}$ at various temperatures. Their size and phase composition were examined by X-ray powder diffraction (XRD), while their size and morphology were studied by scanning electron microscope (SEM). Their absorption infrared spectra were measured by Fourier-transform infrared spectroscopy (FTIR) and magnetic properties were examined by a vibrating sample magnetometer (VSM).

\section{Experimental}

Iron(II) chloride tetrahydrate ( $\geq 99.0 \%$, Sigma-Aldrich) powder was dissolved in $5 \mathrm{~mL}$ of distilled water and added with 
TABLE 1: Synthesis conditions of the iron oxide samples at $75^{\circ} \mathrm{C}$.

\begin{tabular}{|c|c|c|c|c|c|c|c|}
\hline \multirow{2}{*}{ Sample } & \multirow{2}{*}{$\mathrm{Fe}^{2+}(\mathrm{M})$} & \multirow{2}{*}{$\mathrm{Fe}^{3+}(\mathrm{M})$} & \multirow{2}{*}{$\mathrm{NaOH}(\mathrm{M})$} & \multirow{2}{*}{$\mathrm{NH}_{3}$ in $\mathrm{NH}_{4} \mathrm{OH}(\%)$} & \multirow{2}{*}{ Volume ratio $\left(V_{\text {iso }} / V_{\text {water }}\right)$} & \multicolumn{2}{|c|}{ Calcination conditions } \\
\hline & & & & & & Temperature $\left({ }^{\circ} \mathrm{C}\right)$ & Time (h) \\
\hline S1 & 0.09 & & 0.8 & & 10 & & \\
\hline S2 & 0.09 & & 0.8 & & 10 & 300 & 2 \\
\hline S3 & 0.09 & & 0.8 & & 10 & 500 & 2 \\
\hline S4 & 0.4 & & 0.8 & & 10 & & \\
\hline S5 & 0.4 & & 0.8 & & 10 & 300 & 2 \\
\hline $\mathrm{S}^{*}$ & 0.09 & & 0.8 & & 10 & & \\
\hline$S 7^{*}$ & 0.09 & & 0.8 & & 10 & 300 & 2 \\
\hline S8 & 0.09 & & 0.8 & & 0 & & \\
\hline S9 & 0.09 & & & $\geq 28.0$ & 10 & & \\
\hline S10 & 0.09 & & & $\geq 28.0$ & 10 & 530 & 2 \\
\hline S11 & 0.09 & & & $\geq 28.0$ & 10 & 600 & 5 \\
\hline S12 & & 0.1 & & $\geq 28.0$ & 4 & & \\
\hline S13 & & 0.1 & & $\geq 28.0$ & 4 & 400 & 1.7 \\
\hline S14 & & 0.1 & & $\geq 28.0$ & 4 & 600 & 1.7 \\
\hline
\end{tabular}

${ }^{*}$ The sample was synthesized at $90^{\circ} \mathrm{C}$.

$50 \mathrm{~mL}$ of isobutanol ( $\geq 99.0 \%$, Alfa Aesar), leading to two concentrations of $\mathrm{Fe}^{2+}$ ions $(0.09$ and $0.4 \mathrm{M})$. The aqueousorganic mixture was heated to $75^{\circ} \mathrm{C}$, added dropwise for $2 \mathrm{~h}$ with $0.8 \mathrm{M} \mathrm{NaOH}\left(\geq 96.0 \%\right.$, Junsei Chemical) or $\mathrm{NH}_{4} \mathrm{OH}$ $\left(\geq 28.0 \% \mathrm{NH}_{3}\right.$, Junsei Chemical) under constant stirring at $500 \mathrm{rpm}$ to $\mathrm{pH}=11-12$, and further stirred for $30 \mathrm{~min}$. Similarly, iron(III) nitrate enneahydrate ( $\geq 98.0 \%$, Junsei Chemical) was dissolved in $5 \mathrm{~mL}$ of distilled water and added with $20 \mathrm{~mL}$ of isobutanol, resulting in $0.1 \mathrm{M} \mathrm{Fe}^{3+}$ solution. The resulting solution was heated to $75^{\circ} \mathrm{C}$, added dropwise for $2 \mathrm{~h}$ with $\mathrm{NH}_{4} \mathrm{OH}\left(\geq 28.0 \% \mathrm{NH}_{3}\right.$, Junsei Chemical) under constant stirring at $500 \mathrm{rpm}$ to $\mathrm{pH}=11-12$, and further stirred for $30 \mathrm{~min}$. All synthesized iron oxide nanoparticles were washed thrice with distilled water at $75^{\circ} \mathrm{C}$ and dried in an oven at $50^{\circ} \mathrm{C}$. The dried precursors of iron oxide nanoparticles were calcined for $2 \mathrm{~h}$ at 300,500 , and $530^{\circ} \mathrm{C}, 100 \mathrm{~min}$ at 400 and $600^{\circ} \mathrm{C}$, and $5 \mathrm{~h}$ at $600^{\circ} \mathrm{C}$. Their synthesis and calcination conditions are given in Table 1.

The phase composition and size of iron oxide nanoparticles were deduced from measurements by X-ray diffraction (XRD, PANalytical X'pert PRO MPD) with wavelength of $\mathrm{Cu}$ $\mathrm{K}_{\alpha}, 1.5405 \AA$ at room temperature. The size and morphology were measured by an ultrahigh resolution scanning electron microscope (UHR-SEM, Hitachi S-4800). The absorption spectra were obtained by Fourier-transform infrared spectroscopy (FTIR, PerkinElmer Frontier) with a MIR source and an optical KBR beam splitter covering the wavelength range from 2.5 to $25 \mu \mathrm{m}$ (wavenumber range from 4000 to $400 \mathrm{~cm}^{-1}$ ).

The magnetic properties of the iron oxide nanoparticles were examined by a vibrating sample magnetometer (VSM, LakeShore). The magnetization of the nanoparticles was measured as a function of magnetic field strength at room temperature to yield their saturation and remanent magnetization and coercivity.

\section{Results and Discussion}

Figure 1 shows the wide-angle X-ray diffraction (XRD) patterns of samples S1, S6, and S5. Three samples were synthesized with ferrous chloride and $\mathrm{NaOH}$ in isobutanol. Samples S1 and S5 were synthesized at $75^{\circ} \mathrm{C}$ and $\mathrm{S} 6$ at $90^{\circ} \mathrm{C}$. Sample S5 was calcined at $300^{\circ} \mathrm{C}$ for $2 \mathrm{~h}$. All the samples show salient diffraction peaks at $2 \theta=30.2^{\circ}, 35.5^{\circ}, 43.2^{\circ}$, $53.6^{\circ}, 57.1^{\circ}$, and $62.7^{\circ}$ which can be indexed to the cubic structure of magnetite $\left(\mathrm{Fe}_{3} \mathrm{O}_{4}\right)$ with lattice constants $a=$ $8.3750 \AA, b=8.3750 \AA$, and $c=8.3750 \AA$ (reference code 01088-0315). Figure 1(c) suggests that there is no significant phase transformation in the calcination process.

Figure 2 shows the X-ray diffraction (XRD) patterns of samples S12, S13, and S10. The first two samples were synthesized with ferric nitrate and $\mathrm{NH}_{4} \mathrm{OH}$ in isobutanol and sample S10 with ferrous chloride and $\mathrm{NH}_{4} \mathrm{OH}$ in isobutanol. Sample S13 was calcined at $400^{\circ} \mathrm{C}$ for $100 \mathrm{~min}$ and sample S10 at $530^{\circ} \mathrm{C}$ for $2 \mathrm{~h}$. Figures 2 (a) and 2(b) show diffraction peaks at $2 \theta=24.1^{\circ}, 33.1^{\circ}, 35.6^{\circ}, 40.8^{\circ}, 49.4^{\circ}, 54.0^{\circ}, 57.5^{\circ}, 62.4^{\circ}$, and $64.0^{\circ}$ which can be indexed to the rhombohedral structure of hematite $\left(\alpha-\mathrm{Fe}_{2} \mathrm{O}_{3}\right)$ with lattice constants $a=5.0370 \AA$, $b=5.0370 \AA$, and $c=13.7710 \AA$ (reference code 01-089-0596). The phase transformation occurred in sample $S 10$ calcined at $530^{\circ} \mathrm{C}$ for $2 \mathrm{~h}$.

The average particle size was estimated from XRD data using Scherrer equation $[15,17]$ :

$$
D=\frac{K \lambda}{\beta \cos \theta},
$$

where $D$ is the average particle size, $K$ the dimensionless shape factor whose typical value is about $0.9, \lambda$ the $\mathrm{X}$ ray wavelength used in XRD ( $\mathrm{Cu} \mathrm{K}_{\alpha}=1.5405 \AA$ ), $\beta$ the broadening of the observed diffraction line at half the maximum intensity in radians, and $\theta$ the Bragg angle. Using 


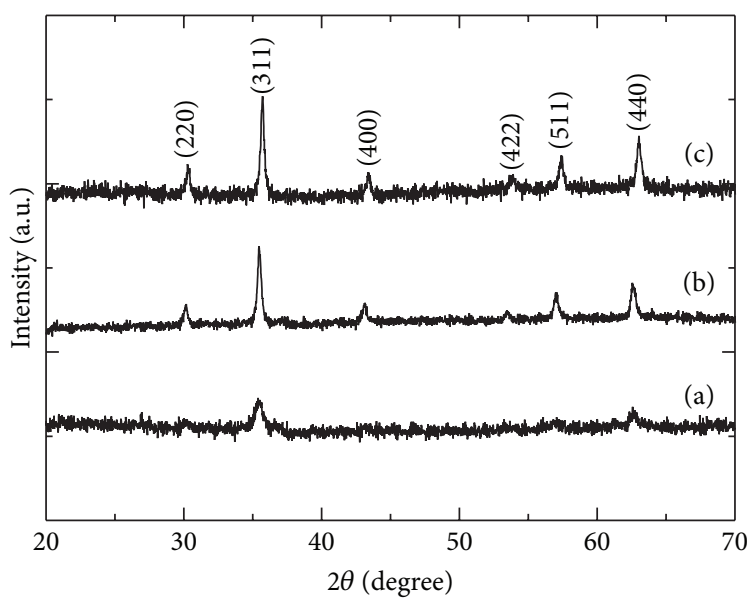

FIGURE 1: XRD patterns of iron oxide samples: (a) $\mathrm{S} 1\left(0.09 \mathrm{M} \mathrm{FeCl}_{2} \cdot 4 \mathrm{H}_{2} \mathrm{O}\right.$ with $0.8 \mathrm{M} \mathrm{NaOH}$ at $\left.75^{\circ} \mathrm{C}\right)$, (b) $\mathrm{S} 6\left(0.09 \mathrm{M} \mathrm{FeCl}_{2} \cdot 4 \mathrm{H}_{2} \mathrm{O}\right.$ with $0.8 \mathrm{M}$ $\mathrm{NaOH}$ at $\left.90^{\circ} \mathrm{C}\right)$, and (c) $\mathrm{S} 5\left(0.4 \mathrm{M} \mathrm{FeCl}_{2} \cdot 4 \mathrm{H}_{2} \mathrm{O}\right.$ with $0.8 \mathrm{M} \mathrm{NaOH}$ at $75^{\circ} \mathrm{C}$ and calcined at $300^{\circ} \mathrm{C}$ for $\left.2 \mathrm{~h}\right)$.

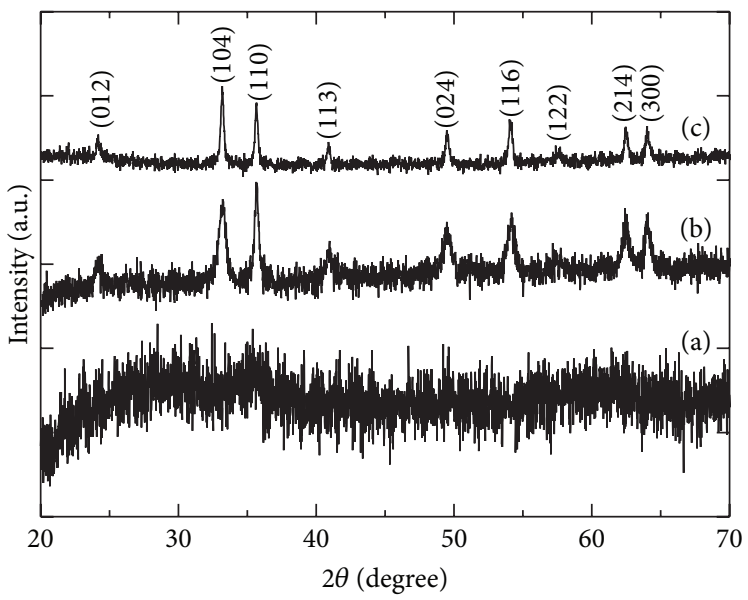

FIGURE 2: XRD patterns of iron oxide samples: (a) $\mathrm{S} 12\left(0.1 \mathrm{M} \mathrm{Fe}\left(\mathrm{NO}_{3}\right)_{3} \cdot 9 \mathrm{H}_{2} \mathrm{O}\right.$ with $\mathrm{NH}_{4} \mathrm{OH}(28.0 \%)$ at $\left.75^{\circ} \mathrm{C}\right) ;\left(\right.$ b) $\mathrm{S} 13\left(0.1 \mathrm{M} \mathrm{Fe}\left(\mathrm{NO}_{3}\right)_{3} \cdot 9 \mathrm{H}_{2} \mathrm{O}\right.$ with $\mathrm{NH}_{4} \mathrm{OH}(28.0 \%)$ at $75^{\circ} \mathrm{C}$ and calcined at $400^{\circ} \mathrm{C}$ for $\left.100 \mathrm{~min}\right)$; and (c) $\mathrm{S} 10\left(0.09 \mathrm{M} \mathrm{FeCl}_{2} \cdot 4 \mathrm{H}_{2} \mathrm{O}\right.$ with NH $\mathrm{H}_{4} \mathrm{OH}(28.0 \%)$ at $75^{\circ} \mathrm{C}$ and calcined at $530^{\circ} \mathrm{C}$ for $2 \mathrm{~h}$ ).

the diffraction peaks at $2 \theta=30.2^{\circ}, 35.5^{\circ}, 43.2^{\circ}, 53.6^{\circ}, 57.1^{\circ}$, and $62.7^{\circ}$, the average crystallite size of samples S4 to S8 was deduced to be $28,31,31,23$, and $56 \mathrm{~nm}$, respectively. The average particle size of S 8 synthesized without isobutanol turned out to be the largest, implying that isobutanol played a role of a surfactant to some extent and contributed to the reduction of the nanoparticle size. Using the diffraction peaks at $2 \theta=24.1^{\circ}, 33.1^{\circ}, 35.6^{\circ}, 40.8^{\circ}, 49.4^{\circ}, 54.0^{\circ}, 57.5^{\circ}, 62.4^{\circ}$, and $64.0^{\circ}$, the average crystallite size of samples S10, S11, S13, and S14 was deduced to be $27,30,21$, and $28 \mathrm{~nm}$, respectively.

Figure 3 shows FTIR spectra of iron oxide samples S1, S3, S5, and S14. Their characteristic wavenumbers are listed in Table 2 along with ten other samples. IR bands of 575 and $420 \mathrm{~cm}^{-1}$ in Figure 3(a), 557 and $443 \mathrm{~cm}^{-1}$ in Figure 3(b), 637,559 , and $441 \mathrm{~cm}^{-1}$ in Figure 3(c), and 539 and $448 \mathrm{~cm}^{-1}$ in Figure 3(d) are due to the Fe-O bonds in tetrahedral and octahedral sites, which are shifted from the corresponding bands of bulk $\mathrm{Fe}_{3} \mathrm{O}_{4}$ around 570 and $375 \mathrm{~cm}^{-1}$ [17]. IR bands of 635 and $559 \mathrm{~cm}^{-1}$ of sample S2 and 637 and $559 \mathrm{~cm}^{-1}$ of sample S5 in Table 2 are characteristic peaks of maghemite [17], implying that calcination at $300^{\circ} \mathrm{C}$ for $2 \mathrm{~h}$ contributed to its phase transformation. The similar IR bands in Table 2 are present in sample S7 at 638 and $561 \mathrm{~cm}^{-1}$. Samples S2, S5, and S7 contain maghemite mixed with magnetite. The IR band in the vicinity of $3400 \mathrm{~cm}^{-1}$ arises from $-\mathrm{OH}$ [15] or water molecules on the sample surface [17]. The absorption peaks around 1629 and $1384 \mathrm{~cm}^{-1}$ in Figure 3(a) are due to $\mathrm{C}=\mathrm{O}$ vibrations [15]. The IR bands at 539 and $448 \mathrm{~cm}^{-1}$ in sample S14 are characteristic of hematite and related to the band near $635 \mathrm{~cm}^{-1}$ in maghemite. The synthesis of magnetite and maghemite can be accomplished using isobutanol with ferrous salt and $\mathrm{NaOH}$. Similarly, hematite was synthesized using isobutanol with ferric nitrate and ammonium hydroxide, which was confirmed by XRD and FTIR results.

SEM micrographs of samples S1 to S14 are shown in Figures $4-7$. The average crystalline sizes of all the samples were deduced from SEM micrographs and are listed in Table 3 with those deduced from the XRD data using (1). Samples S1 


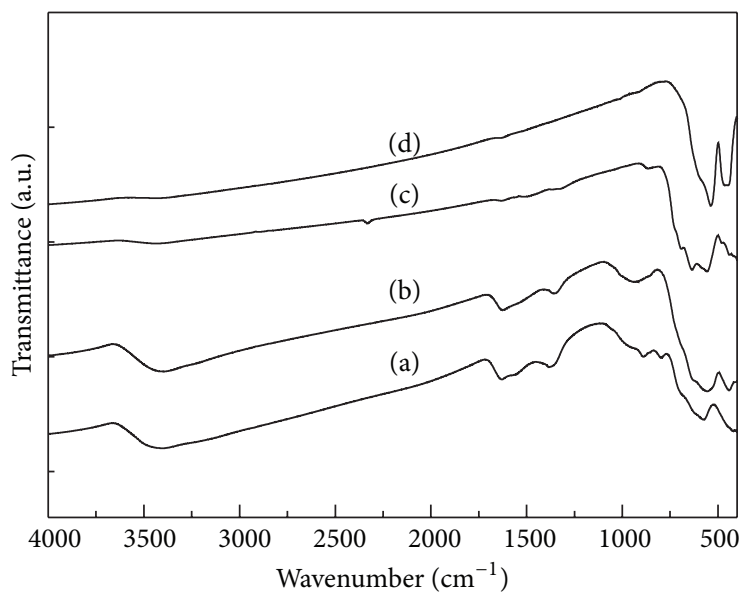

FIgURE 3: FTIR spectra of four iron oxide samples: (a) $\mathrm{S} 1\left(0.09 \mathrm{M} \mathrm{FeCl}_{2} \cdot 4 \mathrm{H}_{2} \mathrm{O}\right.$ with $0.8 \mathrm{M} \mathrm{NaOH}$ at $\left.75^{\circ} \mathrm{C}\right)$, (b) $\mathrm{S} 3\left(0.09 \mathrm{M} \mathrm{FeCl}_{2} \cdot 4 \mathrm{H}_{2} \mathrm{O}\right.$ with $0.8 \mathrm{M} \mathrm{NaOH}$ at $90^{\circ} \mathrm{C}$ and calcined at $500^{\circ} \mathrm{C}$ for $\left.2 \mathrm{~h}\right)$, (c) $\mathrm{S} 5\left(0.4 \mathrm{M} \mathrm{FeCl}_{2} \cdot 4 \mathrm{H}_{2} \mathrm{O}\right.$ with $0.8 \mathrm{M} \mathrm{NaOH}$ at $75^{\circ} \mathrm{C}$ and calcined at $300^{\circ} \mathrm{C}$ for $\left.2 \mathrm{~h}\right)$, and (d) $\mathrm{S} 14\left(0.1 \mathrm{M} \mathrm{Fe}\left(\mathrm{NO}_{3}\right)_{3} \cdot 9 \mathrm{H}_{2} \mathrm{O}\right.$ with $\mathrm{NH}_{4} \mathrm{OH}$ at $\left.75^{\circ} \mathrm{C}\right)$.

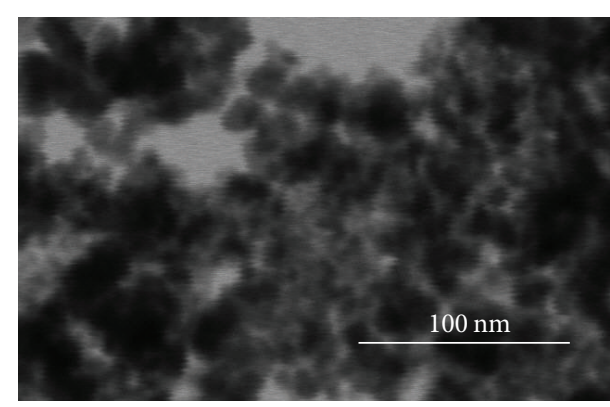

(a)

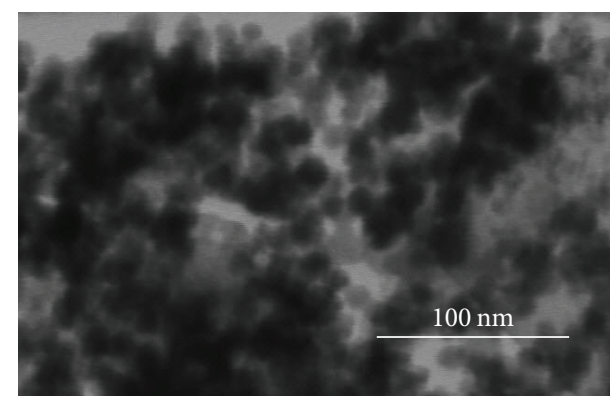

(c)

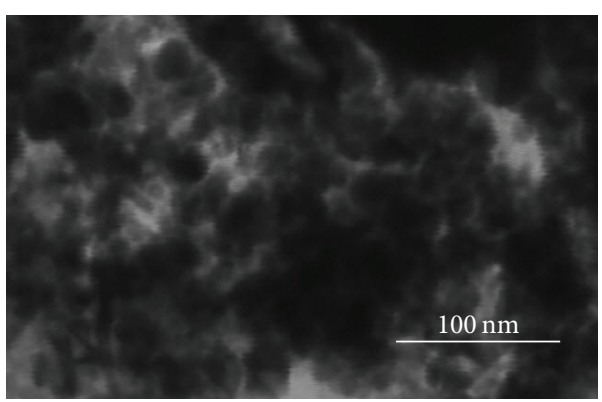

(e)

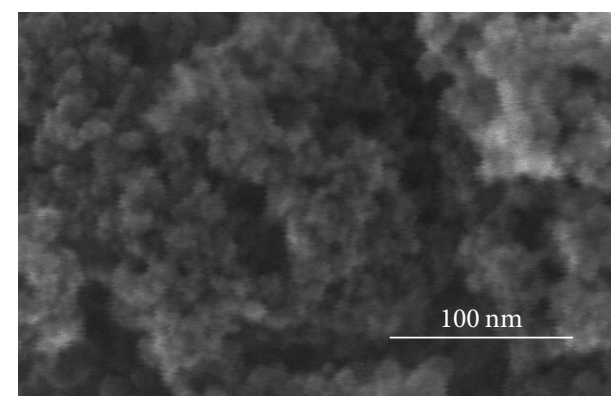

(b)

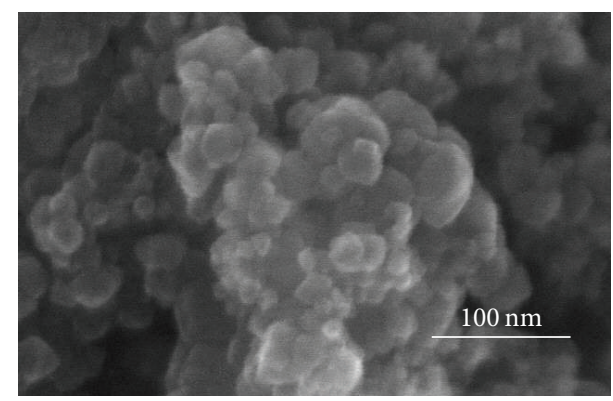

(d)

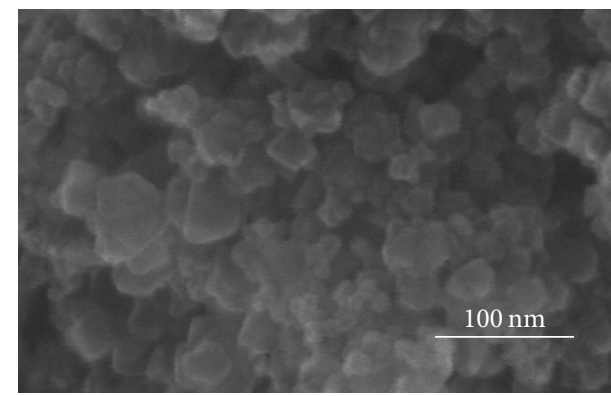

(f)

FIGURE 4: SEM micrographs of iron oxide samples synthesized from $0.09 \mathrm{M} \mathrm{FeCl}_{2} \cdot 4 \mathrm{H}_{2} \mathrm{O}$ with $0.8 \mathrm{M} \mathrm{NaOH}$ at $75^{\circ} \mathrm{C}$ : (a, b) $\mathrm{S} 1$ as synthesized; (c, d) S2 calcined at $300^{\circ} \mathrm{C}$ for $2 \mathrm{~h}$; (e, f) S3 calcined at $500^{\circ} \mathrm{C}$ for $2 \mathrm{~h}$. 


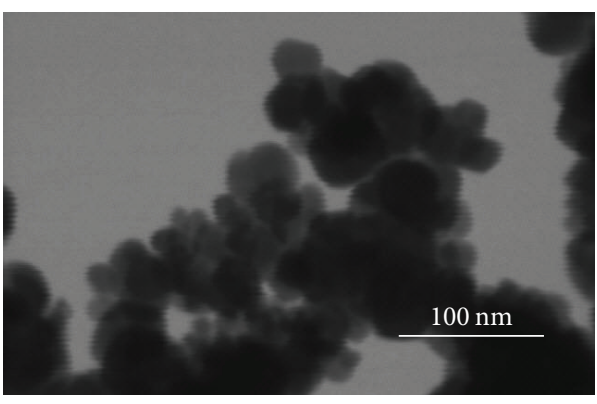

(a)

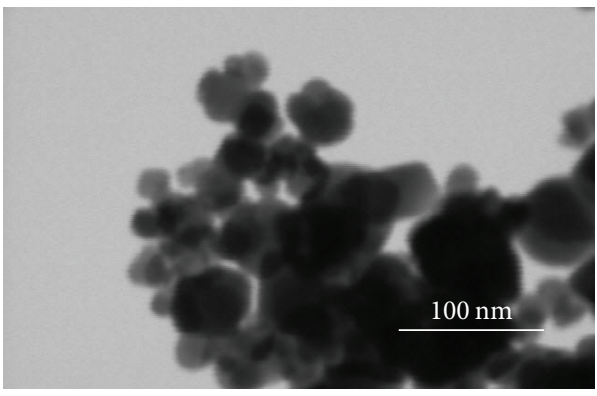

(c)

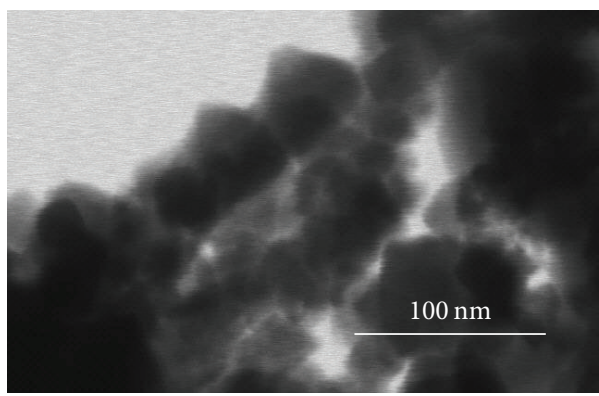

(e)

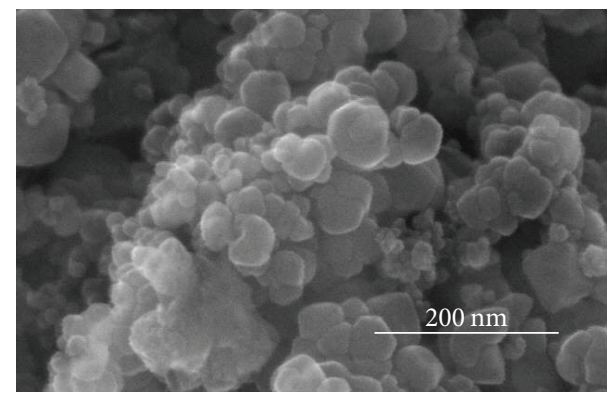

(b)

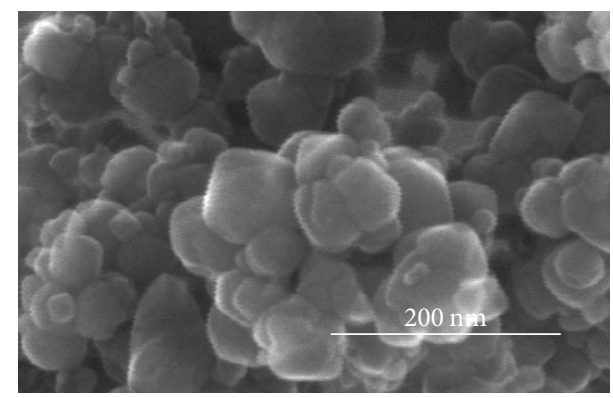

(d)

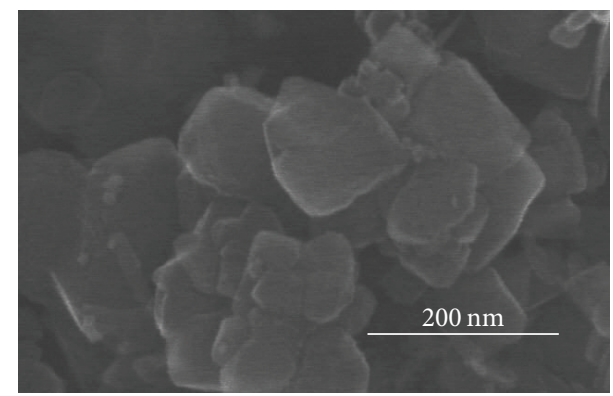

(f)

Figure 5: SEM micrographs of iron oxide samples: (a, b) S4 $\left(0.4 \mathrm{M} \mathrm{FeCl}_{2} \cdot 4 \mathrm{H}_{2} \mathrm{O}\right.$ with $0.8 \mathrm{M} \mathrm{NaOH}$ at $\left.75^{\circ} \mathrm{C}\right) ;(\mathrm{c}, \mathrm{d}) \mathrm{S} 5\left(0.4 \mathrm{M} \mathrm{FeCl} \cdot 4 \mathrm{H}_{2} \mathrm{O}\right.$ with $0.8 \mathrm{M} \mathrm{NaOH}$ at $75^{\circ} \mathrm{C}$ and calcined at $300^{\circ} \mathrm{C}$ for $\left.2 \mathrm{~h}\right) ;(\mathrm{e}, \mathrm{f}) \mathrm{S} 8\left(0.09 \mathrm{M} \mathrm{FeCl}_{2} \cdot 4 \mathrm{H}_{2} \mathrm{O}\right.$ with $0.8 \mathrm{M} \mathrm{NaOH}$ at $\left.75^{\circ} \mathrm{C}\right)$.

to S11 were synthesized with ferrous chloride, while samples S12 to S14 were synthesized with ferric nitrate. The average particles of sample S1 in Figures 4(a) and 4(b) are smaller than those of S2 in Figures 4(c) and 4(d) and S3 in Figures 4(e) and $4(\mathrm{f})$. Calcination at 300 and $500^{\circ} \mathrm{C}$ for $2 \mathrm{~h}$ contributed to increase of the average particle sizes from 11 to $22 \mathrm{~nm}$.

The average particle size of sample S4 in Figures 5(a) and 5(b) and Table 3 is larger than that of S1, indicating that the average nanoparticle size increased from 11 to $30 \mathrm{~nm}$ as the concentration of ferrous chlorides increased from 0.09 to 0.4 M. The average particle size of sample S5 slightly increased due to calcination as seen in Figure 4. The much larger sizes of sample S8 in Figures 5(e) and 5(f) synthesized without isobutanol demonstrated that the role of isobutanol was a crucial size-determining factor in the process. The particle sizes of sample S6 in Figures 6(a) and 6(b) and Table 3 are larger than those of samples S1 to S5. This suggests that the particle sizes increased as synthesis temperature changed from 75 to $90^{\circ} \mathrm{C}$. The average particle size of sample S7 deduced from Figures 6(a) and 6(b) disagrees with the value estimated with (1) from the corresponding XRD data.

Figures 7(a), 7(b), and 7(c) show SEM micrographs of samples S9 to S11, respectively. They were synthesized with ferrous chloride and ammonium hydroxide in isobutanol. The particle sizes of sample S9 in Figure 7(a) are much widely distributed and larger than those in samples S10 in Figure 7(b) and S11 in Figure 7 (c) calcined at 530 and $600^{\circ} \mathrm{C}$, respectively. Figures 7(d), 7(e), and 7(f) show SEM micrographs of samples S12 to S14, respectively. They were synthesized with ferric nitrate and ammonium hydroxide in isobutanol. The average particle size of sample S12 in Figure $7(\mathrm{~d})$ turned out to be $8 \mathrm{~nm}$, which was the smallest among them. The average particle size of sample S13 in Figure 7(e) agrees reasonably well with that of XRD, while the corresponding size of sample S14 in Figure 7(f) is slightly off from that of XRD as seen in sample S7. As shown in Table 3, the values of the average particle sizes deduced from SEM micrographs and their corresponding XRD agree reasonably well in samples S4, S5, 


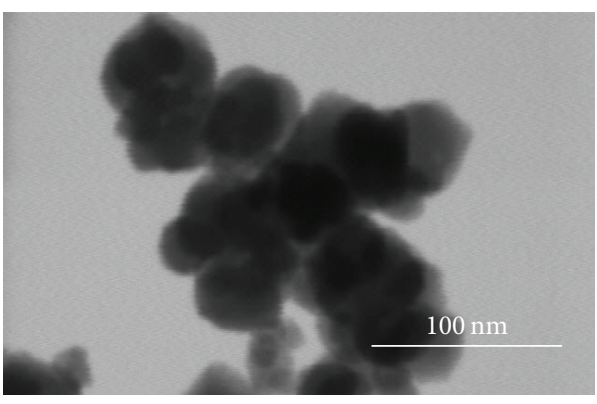

(a)

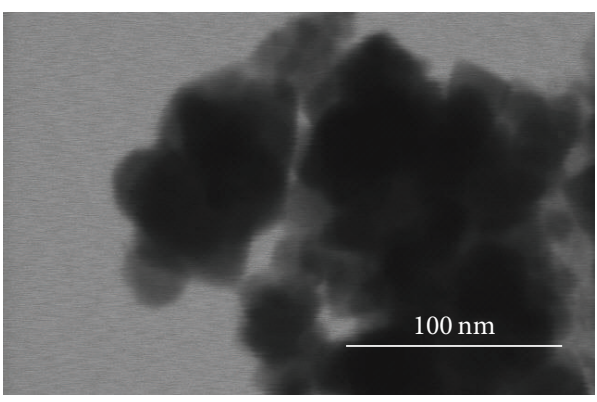

(c)

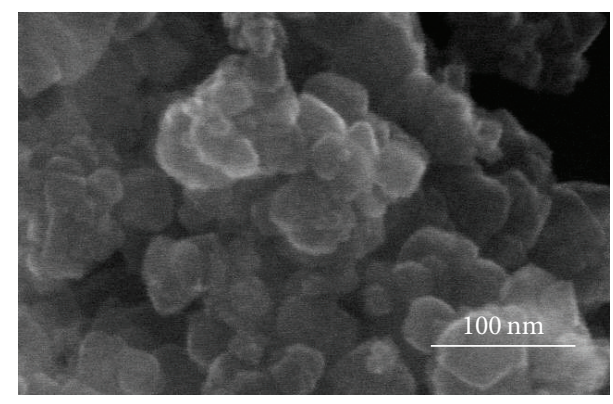

(b)

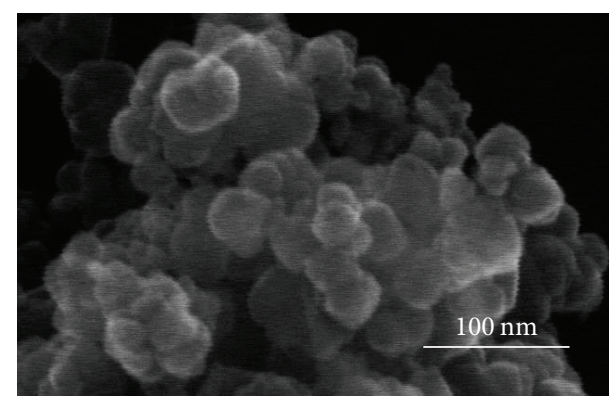

(d)

Figure 6: SEM micrographs of iron oxide samples synthesized with $0.09 \mathrm{M} \mathrm{FeCl}_{2} \cdot 4 \mathrm{H}_{2} \mathrm{O}$ with $0.8 \mathrm{M} \mathrm{NaOH}$ at $90^{\circ} \mathrm{C}$ : (a, b) S6 as synthesized; (c, d) S7 calcined at $300^{\circ} \mathrm{C}$ for $2 \mathrm{~h}$.

TABLE 2: Major wavenumbers of FTIR spectra for the iron oxide samples in Table 1.

\begin{tabular}{ll}
\hline Sample & Wavenumbers $\left(\mathrm{cm}^{-1}\right)$ \\
\hline S1 & $419.59,575.25,796.76,888.22,1383.92,1629.02,3401.07$ \\
S2 & $443.08,558.99,634.88,933.03,1357.53,1626.29,3401.3$ \\
S3 & $443.01,557.13,939.86,1359.04,1628.4,3400.44$ \\
S4 & $573.97,1633.71,3436.08$ \\
S5 & $441.05,559.03,637.29,692.38,3437.23$ \\
S6 & $576.89,892.32,3463.38$ \\
S7 & $441.14,560.87,637.5,870.69,1384.04,1631.02,3433.61$ \\
S8 & $575.69,1384.46,3465.38$ \\
S9 & $416.14,635.59,1401.56,1633.84,1748.14,2807.79,3151.05$ \\
S10 & $470.77,542.93$ \\
S11 & $442.4,540.19$ \\
S12 & $447.48,1384.16,1489.03,1630.34,3392.24(D I 39-1)$ \\
S13 & $459.13,535.07,1629.59,3393.51$ \\
S14 & $447.58,538.95$ \\
\hline
\end{tabular}

${ }^{*}$ Synthesis temperature was $90^{\circ} \mathrm{C}$.

S6, S8, S10, S11, and S13, while those in samples S7 and S14 disagree to some extent.

The magnetic hysteresis curves were measured at room temperature for samples S1 to S8 and their coercivity, the remanent magnetization and the saturation magnetization are listed in Table 4, and the magnetic hystereses of samples S1, S2, S4, and S5 are shown in Figures 8(a), 8(b), 8(c), and $8(d)$, respectively. Samples S1 and S2 were synthesized with
TABLE 3: Average nanoparticle size for the iron oxide samples from SEM and XRD.

\begin{tabular}{lcc}
\hline \multirow{2}{*}{ Sample } & \multicolumn{2}{c}{ Average particle size $(\mathrm{nm})$} \\
& SEM & $\mathrm{XRD}^{+}$ \\
\hline S1 & $11 \pm 4$ & \\
S2 & $22 \pm 5$ & \\
S3 & $22 \pm 9$ & $28.2 \pm 4.5$ \\
S4 & $30 \pm 13$ & $31.2 \pm 12.5$ \\
S5 & $34 \pm 13$ & $31.1 \pm 7.5$ \\
S6 & $39 \pm 13$ & $23.2 \pm 7.9$ \\
S7 & $48 \pm 12$ & $55.8 \pm 29.8$ \\
S8 & $52 \pm 30$ & \\
S9 & $42 \pm 22$ & $27.2 \pm 6.5$ \\
S10 & $35 \pm 7$ & $29.6 \pm 4.7$ \\
S11 & $32 \pm 14$ & \\
S12 & $8 \pm 1$ & $20.7 \pm 6.9$ \\
S13 & $16 \pm 4$ & $28.3 \pm 9.8$ \\
S14 & $13 \pm 3$ & \\
\hline
\end{tabular}

${ }^{*}$ Synthesis temperature was $90^{\circ} \mathrm{C}$.

${ }^{+}$The size was deduced by the Scherrer equation (1).

$0.09 \mathrm{M} \mathrm{FeCl}_{2} \cdot 4 \mathrm{H}_{2} \mathrm{O}$, while S4 and $\mathrm{S} 5$ were prepared with $0.4 \mathrm{M} \mathrm{FeCl}_{2} \cdot 4 \mathrm{H}_{2} \mathrm{O}$. Samples S2 and S5 were calcined at $300^{\circ} \mathrm{C}$ for $2 \mathrm{~h}$. The saturation magnetization of sample $\mathrm{S} 4$ is nearly 3 times higher than the corresponding value of sample S1. The coercivity value tends to decrease from 32.0 to 16.1 Oe as calcination temperature increases to $500^{\circ} \mathrm{C}$, while the remanent magnetization decreases from 1.27 to $0.32 \mathrm{emu} / \mathrm{g}$. The 


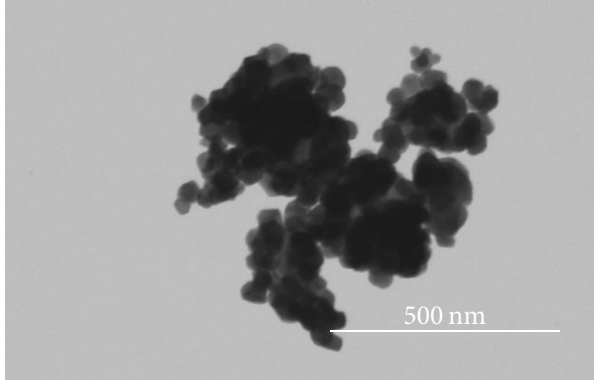

(a)

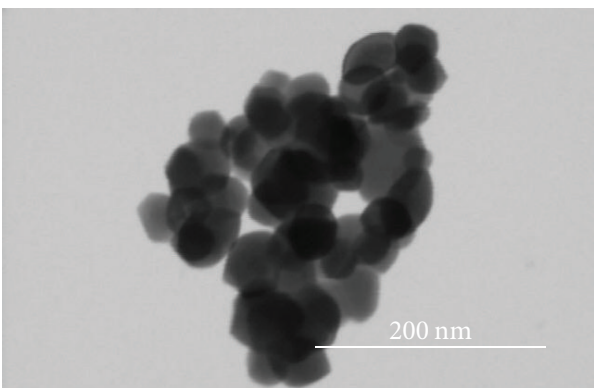

(b)

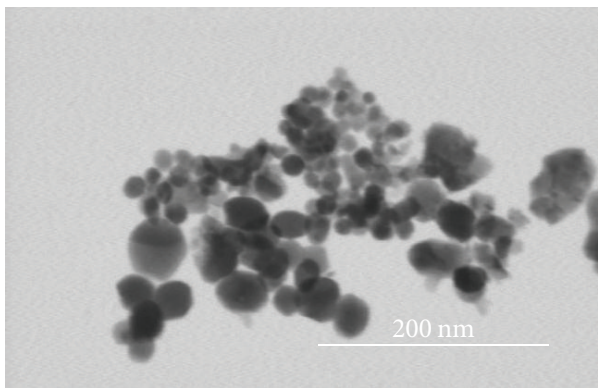

(c)

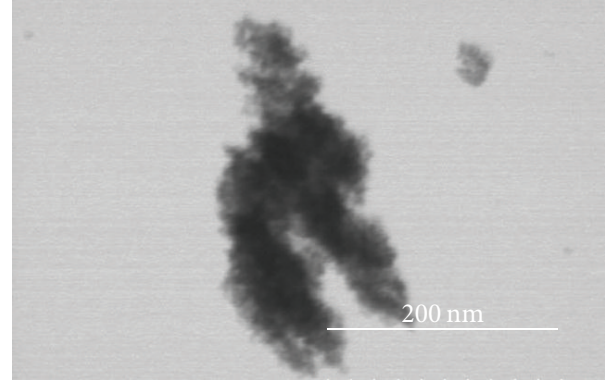

(d)

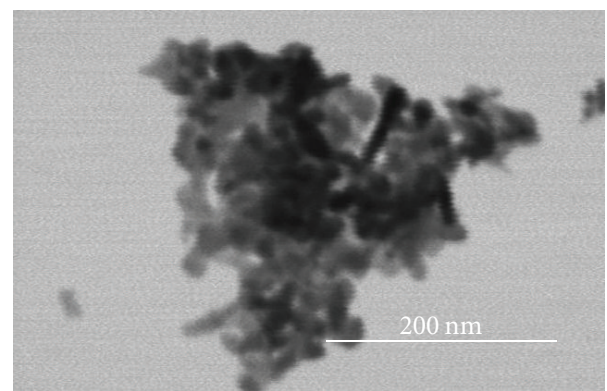

(e)

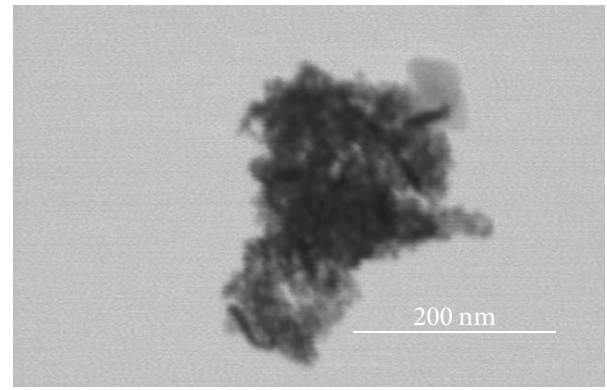

(f)

FIGURE 7: SEM micrographs of iron oxide samples: (a) S9 (0.09 $\mathrm{M} \mathrm{FeCl}_{2} \cdot 4 \mathrm{H}_{2} \mathrm{O}$ with $\mathrm{NH}_{4} \mathrm{OH}(28 \%)$ at $\left.75^{\circ} \mathrm{C}\right) ;\left(\right.$ b) $\mathrm{S} 10\left(0.09 \mathrm{M} \mathrm{FeCl} \cdot 4 \mathrm{H}_{2} \mathrm{O}\right.$ with $\mathrm{NH}_{4} \mathrm{OH}(28 \%)$ at $75^{\circ} \mathrm{C}$ and calcined at $530^{\circ} \mathrm{C}$ for $\left.2 \mathrm{~h}\right)$; (c) $\mathrm{S} 11\left(0.09 \mathrm{M} \mathrm{FeCl}_{2} \cdot 4 \mathrm{H}_{2} \mathrm{O}\right.$ with $\mathrm{NH}_{4} \mathrm{OH}(28 \%)$ at $75^{\circ} \mathrm{C}$ and calcined at $600^{\circ} \mathrm{C}$ for $5 \mathrm{~h})$; (d) $\mathrm{S} 12\left(0.1 \mathrm{M} \mathrm{Fe}\left(\mathrm{NO}_{3}\right)_{3} \cdot 9 \mathrm{H}_{2} \mathrm{O}\right.$ with $\mathrm{NH}_{4} \mathrm{OH}$ at $\left.75^{\circ} \mathrm{C}\right)$; (e) $\mathrm{S} 13\left(0.1 \mathrm{M} \mathrm{Fe}\left(\mathrm{NO}_{3}\right)_{3} \cdot 9 \mathrm{H}_{2} \mathrm{O}\right.$ with $\mathrm{NH}_{4} \mathrm{OH}$ at $75^{\circ} \mathrm{C}$ and calcined at $400^{\circ} \mathrm{C}$ for $100 \mathrm{~min})$; (f) $\mathrm{S} 14\left(0.1 \mathrm{M} \mathrm{Fe}\left(\mathrm{NO}_{3}\right)_{3} \cdot 9 \mathrm{H}_{2} \mathrm{O}\right.$ with $\mathrm{NH}_{4} \mathrm{OH}$ at $75^{\circ} \mathrm{C}$ and calcined at $600^{\circ} \mathrm{C}$ for $\left.100 \mathrm{~min}\right)$.

TABle 4: Magnetic characteristics of the iron nanoparticle samples synthesized at $75^{\circ} \mathrm{C}$.

\begin{tabular}{lccc}
\hline Sample & $\mathrm{H}_{\mathrm{c}}(\mathrm{Oe})$ & $\mathrm{M}_{\mathrm{rem}}(\mathrm{emu} / \mathrm{g})$ & $\mathrm{M}_{\text {sat }}(\mathrm{emu} / \mathrm{g})$ \\
\hline S1 & 32.0 & 1.27 & 27.0 \\
S2 & 21.3 & 0.73 & 25.8 \\
S3 & 16.1 & 0.53 & 25.4 \\
S4 & 73.5 & 7.62 & 72.1 \\
S5 & 39.8 & 4.43 & 64.3 \\
S6 $^{*}$ & 44.0 & 4.39 & 60.1 \\
S7 & 54.7 & 4.82 & 58.2 \\
S8 & 129 & 12.1 & 80.7 \\
\hline
\end{tabular}

${ }^{*}$ Synthesis temperature was $90^{\circ} \mathrm{C}$.

smaller values of the coercivity and remanent magnetization are related to superparamagnetic properties. As shown in Figures 8(a) and 8(b) and Table 4, samples S1, S2, and S3 exhibited superparamagnetic properties at room temperature $[15,17]$. Their corresponding sizes were 11,22 , and $22 \mathrm{~nm}$, respectively. The coercivities and remanent magnetizations of samples S4 to S8 in Table 4 range from 39.8 to 129 Oe and from 4.39 to $12.1 \mathrm{emu} / \mathrm{g}$, respectively, whose values were rather high so that they failed to exhibit superparamagnetic behavior. The values of the coercivity and remanent magnetization are the largest in sample S8 as $129 \mathrm{Oe}$ and $12.1 \mathrm{emu} / \mathrm{g}$, respectively. Sample S8 was synthesized without isobutanol, whose particle sizes were widely distributed around its average of $52 \mathrm{~nm}$. Superparamagnetic properties result from nanoparticles that are smaller than their critical size of $25 \mathrm{~nm}$ [4].

\section{Conclusions}

Iron oxide nanoparticles were synthesized as magnetite, maghemite, and hematite using isobutanol. The synthesis process involved precipitation using a single ferrous or ferric salt in isobutanol with sodium hydroxide or ammonium 


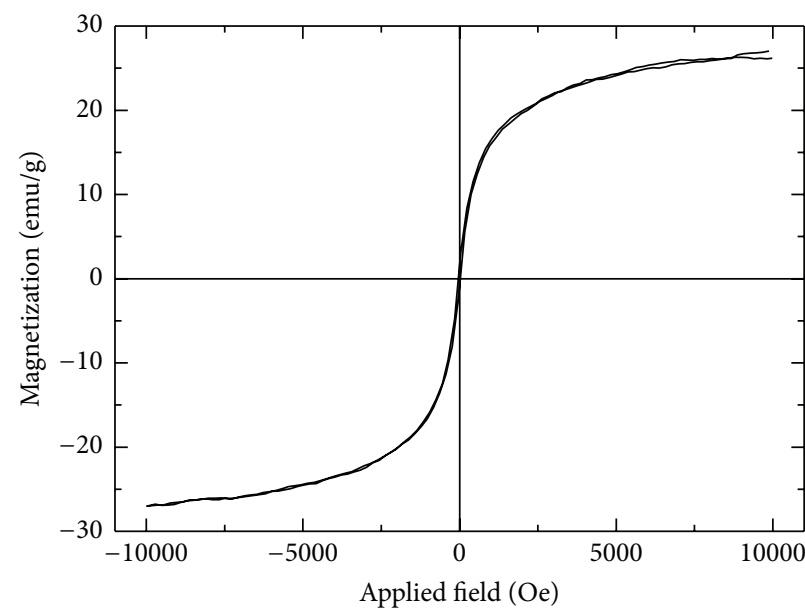

(a) $\mathrm{S} 1$ synthesized at $75^{\circ} \mathrm{C}$

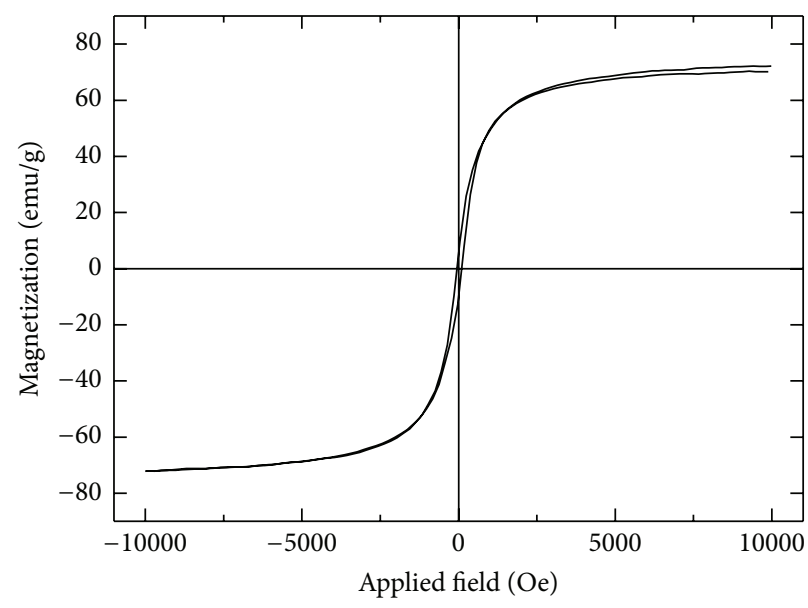

(c) $\mathrm{S} 4$ synthesized at $75^{\circ} \mathrm{C}$

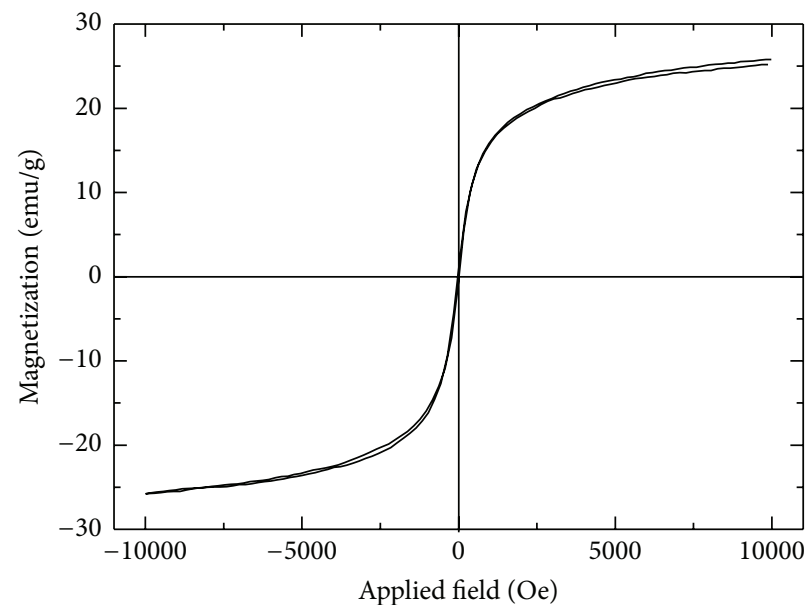

(b) $\mathrm{S} 2$ calcined at $300^{\circ} \mathrm{C}$ for $2 \mathrm{~h}$

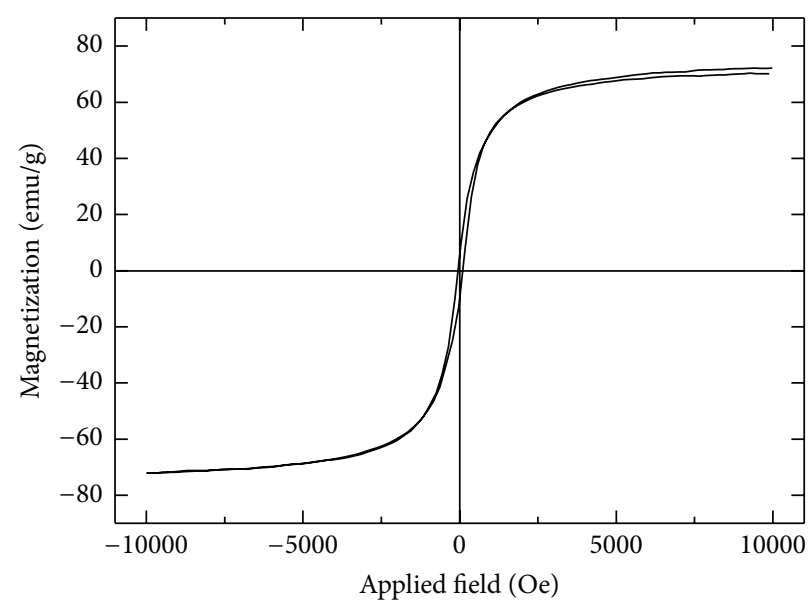

(d) $\mathrm{S} 5$ calcined at $300^{\circ} \mathrm{C}$ for $2 \mathrm{~h}$

Figure 8: Magnetic hysteresis curves measured at room temperature for iron oxide samples: (a) $\mathrm{S} 1\left(0.09 \mathrm{M} \mathrm{FeCl}_{2} \cdot 4 \mathrm{H}_{2} \mathrm{O}\right.$ with $0.8 \mathrm{M} \mathrm{NaOH}$ at $\left.75^{\circ} \mathrm{C}\right)$; (b) S2 $\left(0.09 \mathrm{M} \mathrm{FeCl}_{2} \cdot 4 \mathrm{H}_{2} \mathrm{O}\right.$ with $0.8 \mathrm{M} \mathrm{NaOH}$ at $75^{\circ} \mathrm{C}$ and calcined at $300^{\circ} \mathrm{C}$ for $\left.2 \mathrm{~h}\right)$; (c) $\mathrm{S} 4\left(0.4 \mathrm{M} \mathrm{FeCl}_{2} \cdot 4 \mathrm{H}_{2} \mathrm{O}\right.$ with $0.8 \mathrm{M} \mathrm{NaOH}$ at $\left.75^{\circ} \mathrm{C}\right)$; (d) $\mathrm{S} 5\left(0.4 \mathrm{M} \mathrm{FeCl}_{2} \cdot 4 \mathrm{H}_{2} \mathrm{O}\right.$ with $0.8 \mathrm{M} \mathrm{NaOH}$ at $75^{\circ} \mathrm{C}$ and calcined at $300^{\circ} \mathrm{C}$ for $2 \mathrm{~h}$ ).

hydroxide. Isobutanol played a role of a surfactant in the process. The average size of $\mathrm{Fe}_{3} \mathrm{O}_{4}$ nanoparticles prepared at the lower concentration of ferrous chloride was in the range of $11 \mathrm{~nm}$. The corresponding size increased to 30 and $34 \mathrm{~nm}$ in samples $\mathrm{S} 4$ and $\mathrm{S} 5$ prepared with $0.4 \mathrm{M} \mathrm{FeCl}_{2} \cdot 4 \mathrm{H}_{2} \mathrm{O}$ at $75^{\circ} \mathrm{C}$, while it increased to 39 and $48 \mathrm{~nm}$ in samples $\mathrm{S} 6$ and $\mathrm{S} 7$ prepared with $0.09 \mathrm{M} \mathrm{FeCl}_{2} \cdot 4 \mathrm{H}_{2} \mathrm{O}$ at $90^{\circ} \mathrm{C}$. Phase transformation of magnetite to maghemite occurred in calcining magnetite at $300^{\circ} \mathrm{C}$ for $2 \mathrm{~h}$. As-synthesized and calcined nanoparticles ranging from 11 to $22 \mathrm{~nm}$ prepared at the lower concentration of ferrous chloride at $75^{\circ} \mathrm{C}$ exhibited superparamagnetic properties. Nanoparticles synthesized with ferrous chloride and ammonium hydroxide at $75^{\circ} \mathrm{C}$ and calcined at $530^{\circ} \mathrm{C}$ for $2 \mathrm{~h}$ were $\alpha-\mathrm{Fe}_{2} \mathrm{O}_{3}$ (hematite). Superparamagnetic iron oxide nanoparticles with size of interest using isobutanol are to be stabilized for biomedical applications.

\section{Competing Interests}

The authors declare that they have no competing interests.

\section{References}

[1] A. K. Gupta and M. Gupta, "Synthesis and surface engineering of iron oxide nanoparticles for biomedical applications," Biomaterials, vol. 26, no. 18, pp. 3995-4021, 2005.

[2] A. H. Atta, M. A. El-Ghamry, A. Hamzaoui, and M. S. Refat, "Synthesis and spectroscopic investigations of iron oxide nanoparticles for biomedical applications in the treatment of cancer cells," Journal of Molecular Structure, vol. 1086, pp. 246-254, 2015.

[3] S. Laurent, D. Forge, M. Port et al., "Magnetic iron oxide nanoparticles: synthesis, stabilization, vectorization, physicochemical characterizations, and biological applications," Chemical Reviews, vol. 108, no. 6, pp. 2064-2110, 2008.

[4] I. Karimzadeh, H. R. Dizaji, and M. Aghazadeh, "Development of a facile and effective electrochemical strategy for preparation of iron oxides $\left(\mathrm{Fe}_{3} \mathrm{O}_{4}\right.$ and $\left.\gamma-\mathrm{Fe}_{2} \mathrm{O}_{3}\right)$ nanoparticles from aqueous and ethanol mediums and in situ PVC coating of $\mathrm{Fe}_{3} \mathrm{O}_{4}$ superparamagnetic nanoparticles for biomedical applications," Journal of Magnetism and Magnetic Materials, vol. 416, pp. 8188, 2016. 
[5] E. Augustin, B. Czubek, A. M. Nowicka, A. Kowalczyk, Z. Stojek, and Z. Mazerska, "Improved cytotoxicity and preserved level of cell death induced in colon cancer cells by doxorubicin after its conjugation with iron-oxide magnetic nanoparticles," Toxicology in Vitro, vol. 33, pp. 45-53, 2016.

[6] P. T. Yin, S. Shah, N. J. Pasquale, O. B. Garbuzenko, T. Minko, and K.-B. Lee, "Stem cell-based gene therapy activated using magnetic hyperthermia to enhance the treatment of cancer," Biomaterials, vol. 81, pp. 46-57, 2016.

[7] Y. Jia, M. Yuan, H. Yuan et al., "Co-encapsulation of magnetic $\mathrm{Fe}_{3} \mathrm{O}_{4}$ nanoparticles and doxorubicin into biodegradable PLGA nanocarriers for intratumoral drug delivery," International Journal of Nanomedicine, vol. 7, pp. 1697-1708, 2012.

[8] J. Park, N. R. Kadasala, S. A. Abouelmagd et al., "Polymeriron oxide composite nanoparticles for EPR-independent drug delivery," Biomaterials, vol. 101, pp. 285-295, 2016.

[9] Z. Sun, M. Worden, J. A. Thliveris et al., "Biodistribution of negatively charged iron oxide nanoparticles (IONPs) in mice and enhanced brain delivery using lysophosphatidic acid (LPA)," Nanomedicine: Nanotechnology, Biology and Medicine, vol. 12, no. 7, pp. 1775-1784, 2016.

[10] N. Mallick, M. Anwar, M. Asfer et al., "Chondroitin sulfatecapped super-paramagnetic iron oxide nanoparticles as potential carriers of doxorubicin hydrochloride," Carbohydrate Polymers, vol. 151, pp. 546-556, 2016.

[11] H. Li, K. Yan, Y. Shang et al., "Folate-bovine serum albumin functionalized polymeric micelles loaded with superparamagnetic iron oxide nanoparticles for tumor targeting and magnetic resonance imaging," Acta Biomaterialia, vol. 15, pp. 117-126, 2015.

[12] H. Vu-Quang, M.-K. Yoo, H.-J. Jeong et al., “Targeted delivery of mannan-coated superparamagnetic iron oxide nanoparticles to antigen-presenting cells for magnetic resonance-based diagnosis of metastatic lymph nodes in vivo," Acta Biomaterialia, vol. 7, no. 11, pp. 3935-3945, 2011.

[13] P. I. P. Soares, C. A. T. Laia, A. Carvalho et al., "Iron oxide nanoparticles stabilized with a bilayer of oleic acid for magnetic hyperthermia and MRI applications," Applied Surface Science, vol. 383, pp. 240-247, 2016.

[14] T. K. Jain, S. P. Foy, B. Erokwu, S. Dimitrijevic, C. A. Flask, and V. Labhasetwar, "Magnetic resonance imaging of multifunctional pluronic stabilized iron-oxide nanoparticles in tumor-bearing mice," Biomaterials, vol. 30, no. 35, pp. 6748-6756, 2009.

[15] S. Alibeigi and M. R. Vaezi, "Phase transformation of iron oxide nanoparticles by varying the molar ratio of $\mathrm{Fe}^{2+}: \mathrm{Fe}^{3+}$," Chemical Engineering and Technology, vol. 31, no. 11, pp. 1591-1596, 2008.

[16] S. Babay, T. Mhiri, and M. Toumi, "Synthesis, structural and spectroscopic characterizations of maghemite $\gamma-\mathrm{Fe}_{2} \mathrm{O}_{3}$ prepared by one-step coprecipitation route," Journal of Molecular Structure, vol. 1085, pp. 286-293, 2015.

[17] A. Jafari, S. F. Shayesteh, M. Salouti, and K. Boustani, "Effect of annealing temperature on magnetic phase transition in $\mathrm{Fe}_{3} \mathrm{O}_{4}$ nanoparticles," Journal of Magnetism and Magnetic Materials, vol. 379, pp. 305-312, 2015.

[18] K. S. Rane and V. M. S. Verenkar, "Synthesis of ferrite grade $\gamma$ $\mathrm{Fe}_{2} \mathrm{O}_{3}$," Bulletin of Materials Science, vol. 24, no. 1, pp. 39-45, 2001.

[19] A. B. Chin and I. I. Yaacob, "Synthesis and characterization of magnetic iron oxide nanoparticles via w/o microemulsion and Massart's procedure," Journal of Materials Processing Technology, vol. 191, no. 1-3, pp. 235-237, 2007.
[20] K. Woo, H. J. Lee, J.-P. Ahn, and Y. S. Park, "Sol-gel mediated synthesis of $\mathrm{Fe}_{2} \mathrm{O}_{3}$ nanorods," Advanced Materials, vol. 15, no. 20, pp. 1761-1764, 2003.

[21] E. Herrero, M. V. Cabañas, M. Vallet-Regí, J. L. Martínez, and J. M. González-Calbet, "Influence of synthesis conditions on the $\gamma$ - $\mathrm{Fe}_{2} \mathrm{O}_{3}$ properties," Solid State Ionics, vol. 101-103, no. 1, pp. 213-219, 1997.

[22] S. K. Sahoo, K. Agarwal, A. K. Singh, B. G. Polke, and K. C. Raha, "Characterization of $\gamma$ - and $\alpha-\mathrm{Fe}_{2} \mathrm{O}_{3}$ nano powders synthesized by emulsion precipitation-calcination route and rheological behaviour of $\alpha-\mathrm{Fe}_{2} \mathrm{O}_{3}$," International Journal of Engineering, Science and Technology, vol. 2, no. 8, pp. 118-126, 2010.

[23] K. Woo, J. Hong, S. Choi et al., "Easy synthesis and magnetic properties of iron oxide nanoparticles," Chemistry of Materials, vol. 16, no. 14, pp. 2814-2818, 2004.

[24] T. P. Raming, A. J. A. Winnubst, C. M. van Kats, and A. P. Philipse, "The synthesis and magnetic properties of nanosized hematite $\left(\alpha-\mathrm{Fe}_{2} \mathrm{O}_{3}\right)$ particles," Journal of Colloid and Interface Science, vol. 249, no. 2, pp. 346-350, 2002.

[25] O. Karaagac and H. Kockar, "A simple way to obtain high saturation magnetization for superparamagnetic iron oxide nanoparticles synthesized in air atmosphere: optimization by experimental design," Journal of Magnetism and Magnetic Materials, vol. 409, pp. 116-123, 2016.

[26] E. Alp and N. Aydogan, "A comparative study: synthesis of superparamagnetic iron oxide nanoparticles in air and $\mathrm{N}_{2}$ atmosphere," Colloids and Surfaces A: Physicochemical and Engineering Aspects, 2016. 

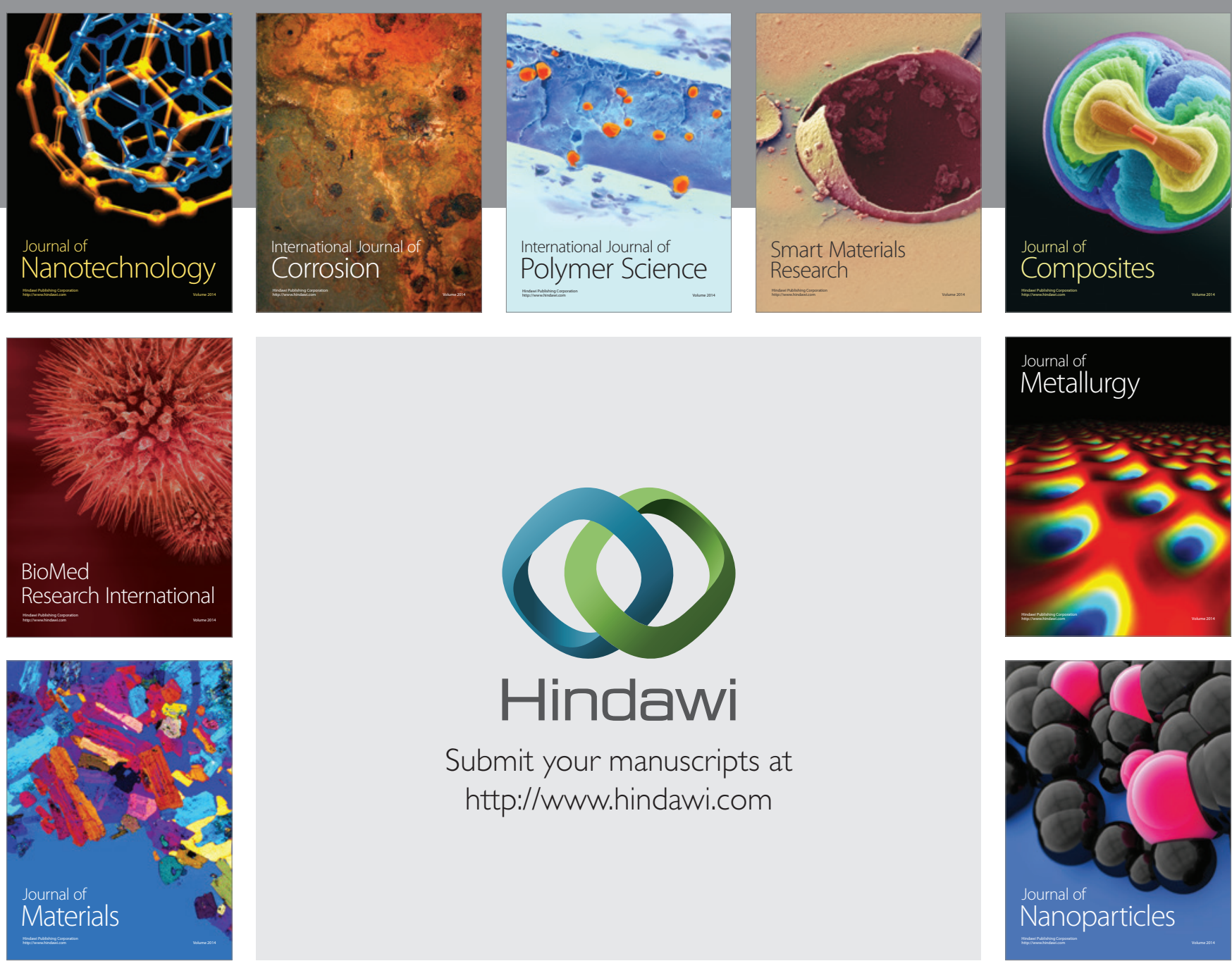

\section{Hindawi}

Submit your manuscripts at

http://www.hindawi.com

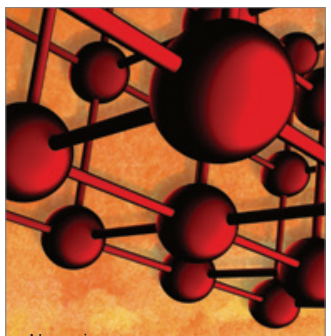

Materials Science and Engineering
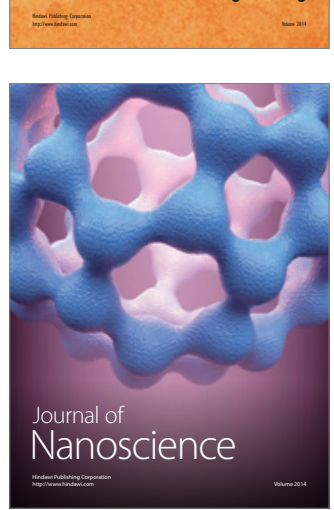
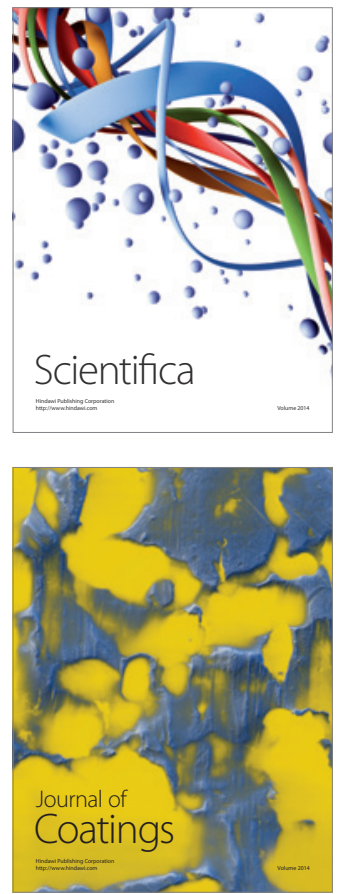
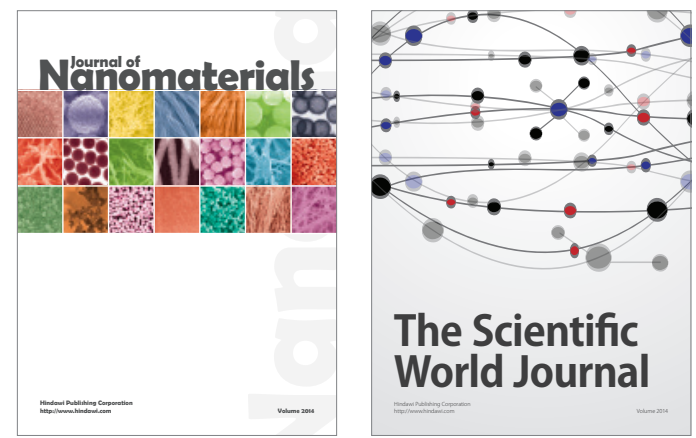

The Scientific World Journal
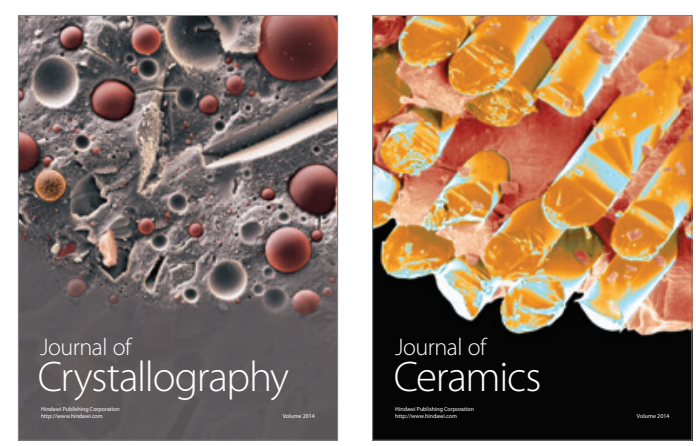
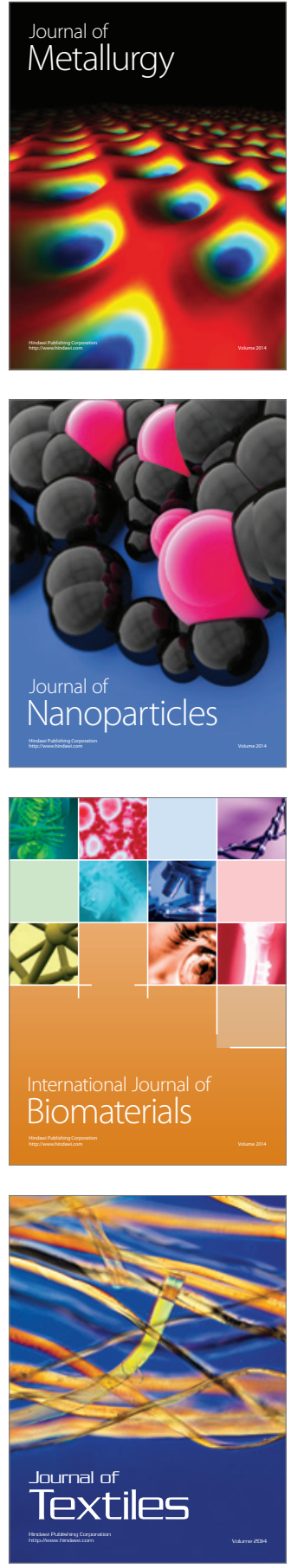